\title{
Oil pipelines and food sovereignty: threat to health equity for Indigenous communities
}

\author{
Michael E. Jonasson ${ }^{1} \cdot$ Samuel J. Spiegel ${ }^{2} \cdot$ Sarah Thomas $^{3}$ - Annalee Yassi ${ }^{1}$. \\ Hannah Wittman ${ }^{4} \cdot$ Tim Takaro $^{5} \cdot$ Reza Afshari $^{1,6} \cdot$ Michael Markwick $^{7}$. \\ Jerry M. Spiegel ${ }^{1}$
}

Published online: 23 September 2019

(c) The Author(s) 2019

\begin{abstract}
Energy projects may profoundly impact Indigenous peoples. We consider effects of Canada's proposed Trans Mountain oil pipeline expansion on the health and food sovereignty of the Tsleil-Waututh Nation (TWN) through contamination and impeded access to uncontaminated traditional foods. Federal monitoring and TWN documentation show elevated shellfish biotoxin levels in TWN's traditional territory near the terminus where crude oil is piped. Although TWN restoration work has reopened some shellfish-harvesting sites, pipeline expansion stands to increase health risk directly through rising bioaccumulating chemical toxins as well as through increased hazardous biotoxins. Climate change from increased fossil fuel use, expected via pipeline expansion, also threatens to increase algae blooms through higher temperature and nutrient loading. As the environmental impact assessment process failed to effectively consider these local health concerns in addition to larger impacts of climate change, new assessment is needed attending to linked issues of equity, sustainability and Indigenous food sovereignty.
\end{abstract}

Keywords Oil pipelines · First Nations · Food sovereignty $\cdot$ Chemical toxins · Biotoxins $\cdot$ Health equity $\cdot$ Environmental impact assessment

Jerry M. Spiegel

jerry.spiegel@ubc.ca

1 School of Population and Public Health (SPPH), University of British Columbia (UBC), 430-2206 East Mall, Vancouver, BC V6T 1Z3, Canada

2 School of Social and Political Science, University of Edinburgh, Edinburgh, UK

3 Tsleil-Waututh Nation, North Vancouver, Canada

4 Centre for Sustainable Food Systems, UBC, Vancouver, BC, Canada

5 Faculty of Health Sciences, Simon Fraser University, Burnaby, Canada

6 British Columbia Centre for Disease Control, Vancouver, Canada

7 School of Communication, Faculty of Business and Professional Studies, Capilano University, North Vancouver, Canada 


\section{The Trans Mountain Pipeline Expansion: challenges to Indigenous sovereignty and health}

Although the United Nation's latest climate report [1] underlines the importance of ending the fossil fuel age, political entanglements of the fossil fuel industry globally have made phase-out tortuously difficult $[2,3]$. The current Canadian government characterizes itself as a leader in the fight against climate change. Yet it seeks to expand Canada's oil exports despite concern about global health impacts and wide public resistance to Canada's expansion of oil pipelines and tanker traffic. Environmentalists and Indigenous communities, especially, have been pushing back. Expanding transportation of the semi-liquid form of crude oil extracted from the Canadian oil sands in the province of Alberta, known as bitumen, will intensify adverse local impacts. These come, for example, from increased exposure to volatile chemicals known to cause respiratory problems [4], increased risk of pipeline fire [5], and greater greenhouse gas emissions with climate change-related health impacts $[6,7]$. The Trans Mountain Pipeline Expansion $[\mathrm{TMX}]$ project is a particularly contentious example, with local, national, and global policy implications [8-10]. Proponents intend to construct a 987-km pipeline from the tar sands in the Canadian interior to Burrard Inlet on Canada's west coast (the terminus), as shown in Fig. 1. The proponents of the project also estimate that the planned expansion of its petroleum storage facility and terminal will trigger a 7-fold increase in marine traffic in the Burrard Inlet [11].

Modelling has shown that a major spill could spread oil across the inlet in 96 hours [11] with a substantial amount landing on beaches [12]. The main petroleum product to be shipped through the TMX project will be diluted bitumen (dilbit), a blend of oil products typically consisting of 70-80\% bitumen and 20-30\% light petroleum condensate (a lighter oil product similar to gasoline) [11]. Aside from being difficult to clean up because it tends to sink after the lighter condensate evaporates and has long-term persistence in the environment [13], shipping it risks exposure of the population to polycyclic aromatic hydrocarbons [PAHs], including the potent carcinogens benzene and benzo[a] pyrene [14, 15]. Benzo[a] pyrene also affects fetal development, with reproductive, neurological, and immunological effects [4]. Chronic exposure to low levels of benzene can also cause hemo-toxicity and immunotoxicity [16].

Despite a direct threat to the local population and concerns about pipeline expansion contributing to additional adverse health impacts of climate change $[10,17]$, the Canadian government agency responsible for conducting impact assessments for Federal projects has not assessed the likely impact of TMX on the health of the Tsleil-Waututh Nation (TWN), an Indigenous nation located at the pipeline terminus, known as the 'People of the Inlet'. TWN is a distinct Coast Salish nation that has continuously and exclusively occupied the territory of eastern Burrard Inlet (including the mouth of the Indian River) for thousands of years, including at least 8 villages and up to 10,000 members before contact with European populations in 1792 C.E. [18, 19]. Stewardship of the land and gathering of traditional foods are important for cultural transmission of Tsleil-Waututh 


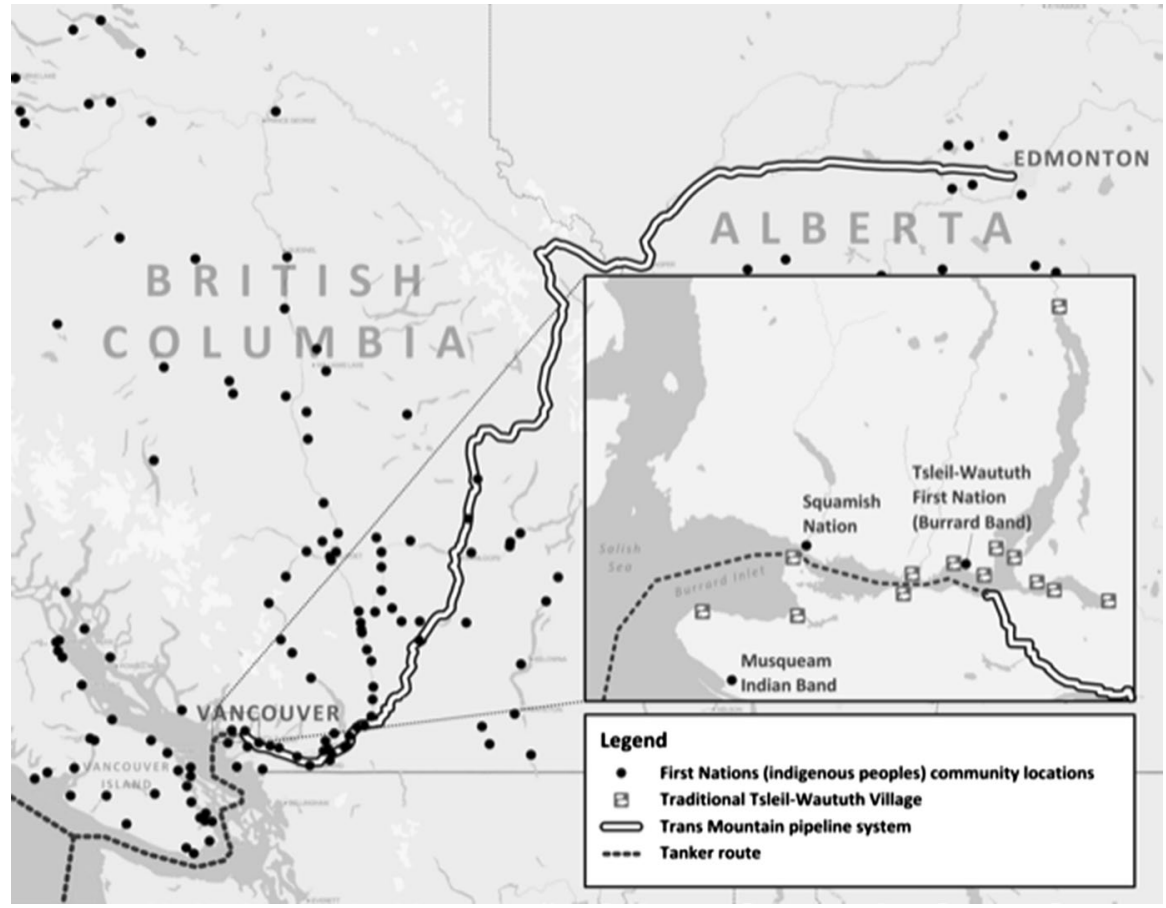

Fig. 1 Trans Mountain Pipeline System and nearby Indigenous communities. Aboriginal Affairs and Northern Development Canada (AANDC) provided the locations of the main Indigenous communities (https://www.aadnc-aandc.gc.ca/DAM/DAM-INTER-AB/STAGING/texte-text/fnamarch11_1315587933 961_eng.pdf. Accessed 2 July 2019) and Province of BC (https://catalogue.data.gov.bc.ca/dataset/first -nation-community-locations. Accessed 28 June 2019); the Wilderness Committee, Vancouver Office spatial provided data on the Trans Mountain pipeline and tanker route (https://www.wildernesscommi ttee.org/news/kinder-morgan-pipeline-watch-map. Accessed 28 June 2019); we derived the locations of traditional Tsleil-Waututh villages from material published by the Tsleil-Waututh Nation without prejudice (https://twnsacredtrust.ca/assessment-report-download/. Accessed 5 May 2019)

knowledge to future generations as TWN continues to inhabit, steward, and govern their traditional territory. Scholars have also noted that this knowledge and the traditional wisdom of ancestral practices provide important insights in environmental management and more broadly, to an equitable transition to a postcarbon future [20-22]. TWN has never ceded control of its traditional territory to either the British, prior to the creation of Canada, or to subsequent Canadian governments that signed treaties with some Indigenous peoples; and TWN has been contesting the TMX since its inception.

Traditional foods for TWN are historically marine, including salmon, herring, and shellfish [18]. Oral histories of diet and archaeological evidence confirm that TWN derived $90 \%$ of their protein from marine resources before contact with European populations [23-28]. The TWN subsistence economy depended on fishingthat also played a central role in religious and ceremonial practices, and feasts [29]. TWN historically collected shellfish in intertidal zones in Burrard Inlet that also 
contributed substantially to TWN's subsistence economy [29]. Besides nutritional benefits, traditional foods are an important part of cultural values and a contributor to mental health [30]. Consuming traditional foods is an essential component of 'cultural continuity' - the contemporary preservation of Indigenous culture, social cohesion within a community, and self-determination [31-33]. Lack of cultural continuity and of traditional foods has also been associated with negative mental health outcomes, including addictions, substance use and suicide, among others [31]. Thus, access to traditional foods represents an important pathway in promoting Indigenous, spiritual, mental, and physical health.

While the availability of traditional foods to Indigenous communities has been greatly reduced, the quality of the remaining traditional Indigenous foods across Canada has also suffered [34]. Among the problems is contamination by several chemicals including PAHs, mercury, and pesticides found in fish and shellfish that bioaccumulate and biomagnify in the food chain. This contamination also leads to reduced consumption of traditional foods by Indigenous people [30]. Despite health advisories from the Canadian government about marine food contamination and regulations that prohibit commercial harvesting of shellfish [35], many Indigenous people still consume these contaminated foods for lack of nutritional alternatives and because they associate them with the underlying health benefits and cultural values [34]. Studies show that chronic and acute exposures to contaminants in traditional foods pose risks for serious health effects including acute hepatotoxicity and chronic diseases such as diabetes and cancer [30, 36, 37]. Decreased intake of traditional foods has also coincided with increased consumption of Western diets high in fat, salt, and sugar [38] associated with increased risk of obesity, diabetes, dental caries, anaemia, and lowered resistance to infection [38]. High-fat, energy-dense diets also increase risk of cardiovascular disease [36].

Negative environmental impacts on food sources affect health equity- the ability of people to achieve their full health potential regardless of their race, socioeconomic status, or other socially determined circumstances [39]. Health equity, in this case, is profoundly impacted by challenges to Indigenous 'food sovereignty'local peoples' self-determined, inherent, never-ceded right to control their own local food systems, ensuring that gathering practices, ecological resources, and policies for labour and land are appropriate and relevant to their local contexts [40, 41]. Food sovereignty thus directly calls into question power relationships among groups within food systems - all participants, organizations, and activities involved in the production, processing, distribution, and consumption of food products-with particular focus on reducing power inequities between Indigenous and non-Indigenous (settler) communities [42, 43].

Indigenous peoples in Canada have experienced profoundly negative impacts on their food sovereignty through processes of colonization-particularly through the Indian Act of 1876. This legislation formally forced Indigenous peoples onto reservations and restricted their movement, hindering their ability to hunt, fish, gather, and sell their local produce. With permission from the Canadian government, private interests, settlers and then later corporations, were accordingly assigned rights to extract timber and mineral resources from Indigenous peoples' traditional territories without their consent [44]. These pressures, reinforced by powerful colonial 
practices such as forced assimilation through residential schools [44, 45] led to loss of healthy foods, and then to declining engagement with traditional foods by younger generations with negative health outcomes [46].

Considerable efforts have been underway to resist these dynamics. The United Nations Declaration on the Rights of Indigenous Peoples (UNDRIP) [47], signed onto by Canada in 2016, affirms "the fundamental importance of the right to selfdetermination of all peoples" and explicitly:

- Includes the right of Indigenous peoples "to practise and revitalize their cultural traditions and customs" (Article 11);

- Specifies a right to "enjoyment of their own means of subsistence and development, and to engage freely in all their traditional and other economic activities" (Article 20);

- Affirms Indigenous peoples' right 'to maintain and strengthen their distinctive spiritual relationship with their traditionally owned or otherwise occupied and used lands, territories, waters and coastal seas and other resources and to uphold their responsibilities to future generations in this regard" (Article 25);

- Acknowledges Indigenous peoples right to the "highest attainable standard of physical and mental health" and that the "States shall take the necessary steps with a view to achieving progressively the full realization of this right" (Article 24) [23].

Indigenous movements of resistance now seek to encourage state actors to uphold these fundamental commitments in practice. As one Indigenous scholar put it: "Decolonization is about realizing that we have power to take back what is rightfully ours and ensure a future for our future generations" [48]. Upholding the rights outlined in UNDRIP is widely seen by Indigenous and many non-Indigenous scholars as key to promoting Indigenous health and health equity. We therefore examine how the Trans Mountain Pipeline Expansion may impact food sovereignty and consequently health equity for the Tsleil-Waututh Nation.

\section{Food sovereignty for the Tsleil-Waututh Nation (TWN): chemical toxicity, biotoxin levels, and the TWN "Burrard Inlet Action Plan"}

Oil spills pose a particularly serious risk, as past spills have been shown to induce elevated levels of PAHs in shellfish tissues. Shellfish can easily take in carcinogenic PAHs and transfer these exposures to human consumers of them [49, 50]. Oil spills are a potent source of PAHs as many bivalves ingest or directly absorb petroleum constituents (and the PAHs present) and bioaccumulate toxicants [51]. Spilled oil can lie trapped under mussel beds for weeks to months and could be readily absorbed and enter food chains [11]. Toxic chemical contamination thus poses a direct health risk to shellfish consumers.

Oil spills and dispersants also affect marine biotoxins. Federal authorities monitored for marine biotoxins (including the neurotoxins saxitoxin, domoic acid, and okadaic acid) in Burrard Inlet in recent decades [18]. Ingestion of these biotoxins 
can produce nerve damage, e.g. paralysis (paralytic shellfish poisoning), permanent short-term memory loss (amnesic shellfish poisoning), and diarrhetic shellfish poisoning [52]. Okadaic acid is also a known tumor promoter in animal models and is suspected to cause colorectal cancer in humans [53, 54]. The Federal government closed Burrard Inlet's Shellfish Harvest in 1972 due to high levels of certain marine biotoxins-without effective communication with Indigenous peoples about the risk. Emerging research suggests an association between oil spills and harmful algae blooms (also known as red tides). Researchers have reported red tides after oil spills and the use of oil dispersants [55].

Experiments using ocean samples and laboratory experiments examining the effects of algal (dinoflagellate) growth showed that separate exposures to crude oil and oil dispersant led to increased levels in algal species that produce the toxin that causes diarrhetic shellfish poisoning. Levels of other algae increased, including $P$. texanum, a bloom-forming dinoflagellate, and two other algal species that produce toxins [55], including $S$. trochoidea, another dinoflagellate that has toxic effects on shellfish larvae, further exposing consumers of shellfish to toxic contamination [55]. Diatoms from specific genera also increase after oil and dispersant exposure [55]; specific species in these genera produce domoic acid, another harmful biotoxin [55].

Observational studies also suggest that levels of potentially harmful algae can increase from oil spills, as reported with reference to the presence of Itxoc I in the Gulf of Mexico in 1979 [56], the Deepwater Horizon oil spill in Offshore Florida, Gulf of Mexico in 2010 [57] and by the Bohai Sea spill in China in 2011) [58]. The effects vary based on oil concentrations [59, 60], use of dispersants [61], nutrientlimited circumstances [62], and types of oil [63, 64]. Ozhan and Bargu [59] showed increased levels of okadaic acid with increased levels of crude oil, which can further contaminate shellfish and threaten the health of shellfish consumers. Oil spills, in addition to directly producing health impacts, can also restrict access to uncontaminated marine resources that could otherwise improve health.

The increased international consumption of oil stimulated through the TMX project will further contribute to climate change, with rising global temperatures also likely increasing harmful algal blooms due to favourable growing conditions in warmer waters [65]. The average number of days above $25{ }^{\circ} \mathrm{C}$ in Burrard Inlet is predicted by local health authorities to triple by 2050 to 60-70 days per year [66]. This temperature may produce dramatic effects on evaporation rates, hence increasing local populations' exposure to the hazardous constituents of dilbit. Increased ocean temperatures can also intensify ocean stratification-where water with different physical properties form horizontal layers that prevent water mixing-and further promote algal growth $[65,67]$. Climate change, with increasing intensity and frequency of extreme rain events, may boost nutrient loading of waterways through sewerage over-flow, septic releases, and agricultural run-off. This too promotes harmful algal blooms $[67,68]$. Increased $\mathrm{CO}_{2}$ atmospheric concentrations may produce harmful algal blooms directly through increased $\mathrm{CO}_{2}$ in water coupled with ocean acidification [68]. Such algal blooms will reverse restoration work done by TWN and threaten their food sovereignty and health.

Water quality monitoring conducted by the British Columbia Ministry of Water, Land and Air Protection in 1991, 1994, 2000, and 2002 showed PAH levels 
exceeding long-term objectives for the inlet [69]. Environment Canada also identified PAHs as a significant sediment contaminant in Burrard Inlet in 1988. Provincial government sampling in 2000 also exceeded water quality objectives in both water and soil samples in Burrard Inlet [70]. Kinder Morgan, the Texas-based company that owned the pipeline until the Canadian government bought it in 2018 (in the midst of the protests), conducted environmental monitoring after the 2007 Westridge Oil Spill but halted this in 2012 [71]. Metro Vancouver previously measured PAH levels in fish tissues every 5 years $[71,72]$ but no government entity currently collects data on the concentrations of PAHs or other chemicals hazards in shellfish tissues in the Burrard Inlet even though previous monitoring conducted by TWN indeed indicated elevated levels of PAHs in shellfish tissues [18]. TWN monitored shellfish biotoxin levels from 2010 to 2013 [73] and now monitors shellfish as part of its Burrard Inlet Action Plan [71]. The Federal Government continues to monitor marine biotoxin levels through the Canadian Shellfish Sanitation Program, an interdepartmental program that aims to ensure shellfish harvested in Canada are safe to eat [51]. Although the values fluctuate from year to year, marine biotoxin levels in Burrard Inlet continue to exceed levels safe for human consumption, representing a health threat to those who consume these toxins in seafood. Anecdotal evidence of higher cancer incidence among TWN families that continued to harvest shellfish than amongst TWN families who abandoned the practice have raised concerns within TWN (personal communication with members of TWN).

To improve the health and integrity of Burrard Inlet, TWN drafted the Burrard Inlet Action Plan in 2015 in partnership with an engineering company to be an Indigenous-led, science-based initiative [71]. The Action Plan aims to achieve its goals by 2025 . Its priorities include improving water quality, assuring consistent monitoring, conserving intertidal habitats, and recovering shellfish beds [71]. Protecting these habitats from additional sources of pollution is essential to restore the inlet and promote the health of marine life providing traditional foods and thereby the health of the Tsleil-Waututh people.

\section{Environmental impact assessment and the importance of health equity}

Canada's National Energy Board (NEB) conducted the Environmental Impact Assessment (EIA) for this project approved in 2016. While typically the Canadian government should be responsible for conducting impact assessments, its recent purchase of the TMX project from the Texas-based Kinder Morgan company has led to concerns about conflict of interest as the government has become both the owner and regulator of the project, prompting calls by civil society groups for an independent health assessment $[6,7,10]$. Amidst widespread protests and arrests of environmental and climate change activists from Indigenous and concerned non-Indigenous populations attempting to block the construction [74, 75], and a court challenge led by TWN-on August 30th 2018 the Federal Court of Appeal overturned the government's prior approval of the project. The Court ordered a new review to consider potential impact of increased tanker traffic on the marine population. Despite 
public health and advocacy group presentations $[6,18,76]$, the ruling did not mention a need to assess the carcinogenic and neurotoxic hazards that threaten the health of local human populations. On 22 February 2019, the NEB again recommended approval. Their Reconsideration Report argued that the benefits of this project for national interests would outweigh the substantial impacts to the Southern resident killer whale (orca) population and Canada's contribution to global greenhouse gas emissions [77].

This report again failed to acknowledge additional credible human health risks including those discussed above and of further loss of Indigenous food sovereignty. Even where the Federal Court of Appeal's ruling addressed the need to consider impact on the orca population [78], the NEB failed; the NEB's reconsideration press release of 22 February 2019 concluded that "Project-related marine shipping is likely to cause significant adverse environmental effects on the Southern resident killer whale and on Indigenous cultural use associated with the Southern resident killer whale", yet approved continuation.

Risks to human health-beyond those related to the disappearance of orcasneed also to be (re)considered. Failure to do so would, in our view, violate both the right to "life, liberty and security of the person", enshrined in Section 7 of the Canadian Charter of Rights and Freedoms, and Canada's obligations under UNDRIP. The omission of human health impacts in the NEB's original review of the TransMountain Pipeline Expansion, repeated in the subsequent court-ordered reconsideration of the project, remains unacceptable. We argue that the health impact of this project on TWN through threats of contamination related to food sovereignty of these Indigenous people is also essential to consider.

While EIAs are among the most important environmental governance tools, recent research in political ecology and other disciplines accentuates limitations of EIAs and their entanglements in political processes [79]. Lack of adequate community consultation, with EIAs conducted "as tokenistic tools to approve developments rather than to genuinely engage with the concerns of interested and affected groups" [80] means that EIAs are increasingly recognized as narrow 'expert' exercises dominated by extractive sector interests while undermining public trust [81].

The Trans Mountain Pipeline Expansion is a powerful illustration of a highly flawed EIA process wedded to an agenda visibly at odds with the UNDRIP (that Canada signed). The TWN, whose health and food sovereignty stand to be further negatively impacted, actively opposed the project. Arguing that the project is not even in the national interest economically, TWN Chief Leah George Wilson emphasized: "The health and well-being of Burrard Inlet is integral to the health and wellbeing of our people, our economy and indeed, who we are as a people" [82]. Nonetheless, on 18 June 2019, the Federal Government again approved this project, and again the approval made no mention of the health concerns or food sovereignty.

Health Impact Assessments (HIAs) include methods to evaluate the human health impacts of policies and programs [83]. Like EIAs, HIAs commonly consist of a 6-stage process of scoping, screening, assessment, recommendations, reporting, and monitoring and evaluation [80]. The methods for HIAs, like EIAs, focus narrowly on the "scoping" and "screening" stages that determine what impacts and factors are included in the assessment $[83,84]$. The HIA for the TMX is no exception [11, 
12]. As other researchers have noted, 'equity-focused' HIAs - that prioritize fair or just health outcomes both within and across populations-are important as projects interact with other stressors to disproportionally affect vulnerable populations across space and time [83]. A recent literature review of equity-focused HIAs found that even when equity is more prominent, many HIAs equate equity with addressing health disparities alone rather than analyzing root causes of injustice [83]. That is, they fail to integrate environment, community, and equity — as in this case.

A recent review of EIA processes for Canada's oil sands extraction concerning Indigenous peoples concluded that "much of the research supporting regulatory decisions has been imbued with a discredited, one-way view of cultural change that pays inadequate attention to ongoing subsistence and spiritual practices" [85]. With the proposed sevenfold increase in tanker traffic through TWN (and other Indigenous territories), the failure of the EIA process to seriously investigate the impact of the Trans Mountain Pipeline Expansion on the subsistence and spiritual practices of the Tsleil-Waututh First Nation (or other Indigenous nations along the pipeline), along with the many health concerns, is consistent with this observation.

\section{Conclusion}

Healthy and nutritious foods are important for improving population health. Canada's EIA process used for this fossil fuel expansion project failed to properly consider health impacts of climate change and the health risks of severe spills. These will affect all the local populations. It also ignored local health concerns specific to Indigenous communities, including the impact on TWN's wellbeing, physical, mental, and spiritual. The Health Officers Council (HOC) of BC, along with the Canadian Medical Association and Doctors of BC, have long called for improving HIAs for major resource development projects. In 2019, the HOC also endorsed a call for an independent comprehensive health impact assessment of the TMX. The analysis reported here supports the conclusion that the current assessment of this project is unacceptable. We assert that a proper HIA is needed to respect Canada's international commitments to UNDRIP and the Paris accord on climate change, and to address the health concerns of both Indigenous and non-Indigenous populations.

Acknowledgements This work was supported in part by the Canadian Institutes of Health Research (CIHR) under grant ROH-115207, "Food systems and health equity in an era of globalization: Think, eat and grow green globally (TEG3)". We thank Karen Lockhart and Steve Barker from University of British Columbia's School of Population and Public Health for their assistance; we are grateful for the comments from an anonymous reviewer, and we respectfully acknowledge that this work was conducted on never ceded Coast Salish Territory-the traditional territories of the Musqueam, Squamish, Tsleil-Waututh and Kwikwetlem First Nations.

Open Access This article is distributed under the terms of the Creative Commons Attribution 4.0 International License (http://creativecommons.org/licenses/by/4.0/), which permits unrestricted use, distribution, and reproduction in any medium, provided you give appropriate credit to the original author(s) and the source, provide a link to the Creative Commons license, and indicate if changes were made. 


\section{References}

1. International Panel on Climate Change. Global warming of $1.5^{\circ}$ C. 2018. https://www.ipcc.ch/site/ assets/uploads/sites/2/2018/07/SR15_SPM_version_stand_alone_LR.pdf. Accessed 11 Feb 2019.

2. Brown B, Spiegel SJ. Coal, climate justice, and the cultural politics of energy transition. Glob Environ Polit. 2019;19(2):1-20.

3. Taft K. Oil's deep state: how the petroleum industry undermines democracy and stops action on global warming-in Alberta, and in Ottawa. Toronto: James Lorimer \& Company; 2017.

4. Environmental Protection Agency. Toxicological review of benzo[a]pyrene. 2017. https://cfpub .epa.gov/ncea/iris/iris_documents/documents/toxreviews/0136tr.pdf. Accessed 11 Feb 2019. Public Health Association of British Columbia. Re: The approval of the expansion of the Kinder Morgan Trans Mountain Pipeline, (press release). Victoria, BC: 2017.

5. Bowcock, C. (2015). Trans Mountain tank farm tactical risk analysis Retrieved from https://www. scribd.com/document/347097591/Burnaby-Fire-Department-Evidentiary-Paper\#download\&from_ embed. Accessed 22 March 2019.

6. Takaro, T. Major human health impacts of the increase in tanker traffic due to the Trans Mountain Pipeline expansion. 2018. https://apps.neb-one.gc.ca/REGDOCS/File/Download/3718220. Accessed 5 May 2019.

7. Public Health Association of British Columbia. Re: The Approval of the Expansion of the Kinder Morgan Trans Mountain Pipeline, (press release). Victoria, BC: 2017.

8. Change SE, Stone J, Demes K, Piscetelli M. Consequences of oil spills: a review and framework for informing planning. Ecology and Society. 2014;19(2).

9. Takaro T, Miller T. Trans Mountain pipeline review must look at impact on global health emergency of climate change 2018. https://www.cbc.ca/news/canada/manitoba/opinion-climate-change-healt h-emergency-1.4871327. Accessed 11 Feb 2019.

10. Takaro T, Hancock T, Howard C, Lavoie C, Brooks-Wilson A. Kinder Morgan and Public Health: The risks of Kinder Morgan's pipeline in your community. 2016. http://world.350.org/vancouver/ files/2017/02/6_Physicians-Report-Kinder-Morgan-and-Public-Health.pdf. Accessed 11 Feb 2019.

11. Short JW. Fate and Effect of Oil Spills from the Trans Mountain Expansion Project in Burrard Inlet and the Fraser River Estuary. 2015. https://vancouver.ca/images/web/pipeline/Jeffrey-Short-dilbi t-and-spill-marine-impact-report.PDF. Accessed 11 Feb 2019.

12. Genwest Systems Inc. Oil Spill Trajectory Modeling Report in Burrard Inlet for the Trans Mountain Expansion Project. 2015. https://twnsacredtrust.ca/wp-content/uploads/.../TWN-Assessment-Appen dix-2.pdf. Accessed 11 Feb 2019.

13. CounterSpil Research Inc. A Review of Countermeasures Technologies for Viscous Oils that Submerge. 2011. https://livingoceans.org/media/reports-publications/review-countermeasures-techn ologies-viscous-oils-submerge. Accessed 11 Feb 2019.

14. CarexCanada. 1,3-Butadiene. 2018. https://www.carexcanada.ca/en/1,3-butadiene/. Accessed 5 May 2019.

15. United States Environmental Protection Agency. Carcinogenic effects of benzene: an update. 1998. https://cfpub.epa.gov/ncea/risk/recordisplay.cfm?deid=2806. Accessed 5 May 2019.

16. U.S. Environmental Protection Agency. Toxicological review of benzene [noncancer effects]. 2002. https://cfpub.epa.gov/ncea/iris/iris_documents/documents/toxreviews/0276tr.pdf. Accessed 5 May 2019.

17. Batterman S. Review of Kinder Morgan Pipeline Expansion Project Application Human Health Impact Assessment Expert Report. 2015. https://livingoceans.org/media/reports-.

18. Tsleil-Waututh, Treaty, Lands \& Resources Department. Assessment of the Trans Mountain Pipeline and Tanker Expansion Proposal. 2016. https://twnsacredtrust.ca/assessment-report-download/. Accessed 5 May 2019.

19. Thunderchild MCB. Tsleil-Waututh health, sickness, disease and treatment: an exploratory ethnography. Doctoral dissertation, University of British Columbia; 1994.

20. Coté C. "Indigenizing" food sovereignty. Revitalizing Indigenous food practices and ecological knowledges in Canada and the United States. Humanities. 2016;5:57.

21. Turner NJ, Davidson-Hunt IJ, O'Flaherty M. Living on the edge: ecological and cultural edges as sources of diversity for social-ecological resilience. Hum Ecol. 2003;31(3):439-61.

22. Turner NJ, Ignace MB, Ignace R. Traditional ecological knowledge and wisdom of aboriginal peoples in British Columbia. Ecol Appl. 2000;10(5):1275-87. 
23. Pierson N. Bridging troubled waters: zooarchaeology and marine conservation on Burrard Inlet, Southwest British Columbia. Burnaby: Simon Fraser University; 2011.

24. Stantec Consulting Limited. Long-Term Monitoring Program 2012 Report: Foreshore Environment Westridge Accidental Hydrocarbon Release. 2012. https://apps.neb-one.gc.ca/REGDOCS/Item/ Open/2684907. Accessed 5 May 2019.

25. Lepofsky D, Trost T, Morin J. Coast Salish interaction: a view from the inlets. Can J Archaeol. 2007;31:190-223.

26. Trost T. Forgotten waters: a zooarchaeological analysis of the Cove Cliff Site (DhRr-18) Indian Arm, British Columbia. Burnaby: Simon Fraser University; 2005.

27. Ham L, Yip S. The 1991 archaeological excavations at the Barnett Highway Sites. British Columbia: Port Moody; 1992. p. 1992.

28. Charlton A. Archaeological investigations at the Cates Park Site (DhRr 8). Victoria: Archaeological Sites Advisory Board; 1974. p. 1974.

29. Morin J. Tsleil-Waututh Nation's History, Culture and Aboriginal Interests in Eastern Burrard Inlet [Redacted Version]. 2015. https://twnsacredtrust.ca/wp-content/uploads/2015/05/Morin-Exper t-Report-PUBLIC-VERSION-sm.pdf. Accessed 5 May 2019.

30. Assembly of First Nations. Traditional Foods: Are they Safe for First Nations Consumption? Ottawa; 2007. https://www.afn.ca/uploads/files/rp-traditional_foods_safety_paper_final.pdf. Accessed 5 May 2019.

31. Oster RT, Grier A, Lightning R, Mayan MJ, Toth EL. Cultural continuity, traditional Indigenous language, and diabetes in Alberta First Nations: a mixed methods study. Int J Equity Health. 2014;13:92.

32. Reading C, Wien F. Health inequalities and social determinants of aboriginal peoples' health. Prince George: National Collaborating Centre for Aboriginal Health; 2009.

33. Auger A. Cultural continuity as a determinant of Indigenous peoples' health: a metasynthesis of qualitative research in Canada and the United States. Int Indig Policy J. 2016;7(4):3.

34. McAuley C, Knopper LD. Impacts of traditional food consumption advisories: compliance, changes in diet and loss of confidence in traditional foods. Environ Health. 2011;10:55.

35. Afshari R, Bellinger DC. Implementing new regulation promotes health but may increase inequality. Asia Pac J Med Toxicol. 2018;7(4):90-1. https://doi.org/10.22038/APJMT.2018.11999.

36. Earle L. Traditional aboriginal diets \& health. Prince George: National Collaborating Centre for Aboriginal Health; 2013.

37. Akande VO, Hendriks AM, Ruiter RAC, Kremers SPJ. Determinants of dietary behavior and physical activity among Canadian Inuit: a systematic review. Int J Behav Nutr Phys Act. 2015;12:84.

38. Fieldhouse $\mathrm{P}$, Thompson $\mathrm{S}$. Tackling food security issues in Indigenous communities in Canada: the Manitoba experience. Nutr Diet. 2012;69(3):217-21.

39. National Collaborating Centre for Determinants of Health. Let's talk health equity. Antigonish: National Collaborating Centre for Determinants of Health; 2013.

40. Wittman H. Food sovereignty: a new rights framework for food and nature? Environ Soc Adv Res. 2011;2:87-105.

41. Weiler AM, Hergesheimer C, Brisbois B, Wittman H, Yassi A, Spiegel JM. Food sovereignty, food security and health equity: a meta-narrative mapping exercise. Health Policy Plan. 2015;30(8):1078-92.

42. Grey S, Patel RC. Food sovereignty as decolonization: some contributions from Indigenous movements to food system and development politics. Agric Hum Values. 2015;32:431-44.

43. Patel RC. Food sovereignty: power, gender, and the right to food. PLoS Med. 2012;9(6):e1001223.

44. Manuel A, Derrickson RM. The reconciliation manifesto: recovering the land, rebuilding the economy. Toronto: James Lorimer and Company Ltd., Publishers; 2017.

45. Truth and Reconciliation Commission of Canada.(2015).Final report of the Truth and Reconciliation Commission of Canada, vol. 1: Summary. Toronto: Lorimer; 2015. http://www.trc.ca/. Accessed 3 August 2019

46. Desmarais AA, Wittman H. Farmers, foodies and First Nations: getting to food sovereignty in Canada. J Peasant Stud. 2014;41(6):1153-73.

47. United Nations. United Nations Declaration on the Rights of Indigenous Peoples. United Nations; 2008. https://www.un.org/esa/socdev/unpfii/documents/DRIPS_en.pdf. Accessed 5 May 2019.

48. Palmater P. Decolonization is taking back our power. In: McFarlane P, Schabas N, editors. "Whose Land is it Anyway" A Manual for Decolonization: Federation of Post-Secondary Educators of BC; 2017. p. 78. 
49. Duffy LK, Bowyer RT, Testa JW, Faro JB, editors. Acute phase proteins and cytokines in Alaskan mammals as markers of chronic exposure to environmental pollutants. American Fisheries Society Symposium 1996; 1996.

50. Sharp B, Cody M, Turner R, editors. Effects of the Exxon Valdez oil spill on the black oystercatcher. American Fisheries Society Symposium; 1996.

51. Widdows J, Donkin P, Brinsley M, Evans S, Salkeld P, Franklin A, et al. Scope for growth and contaminant levels in North Sea mussels Mytilus edulis. Mar Ecol Prog Ser. 1995;123(1/3):131-48.

52. Canadian Food Inspection Agency. Marine Toxins in Bivalve Shellfish: Paralytic Shellfish Poisoning, Amnesic Shellfish Poisoning and Diarrhetic Shellfish Poisoning 2017. http://www.inspection .gc.ca/food/information-for-consumers/fact-sheets-and-infographics/products-and-risks/fish-andseafood/toxins-in-shellfish/eng/1332275144981/1332275222849. Accessed 5 May 2019.

53. Valdiglesias V, Prego-Faraldo MV, Pásaro E, Méndez J, Laffon B. Okadaic acid: more than a diarrheic toxin. Mar Drugs. 2013;11(11):4328-49.

54. Manerio E, Rodas VL, Costas E, Hernandez JM. Shellfish consumption: a major risk factor for colorectal cancer. Med Hypotheses. 2008;70(2):409-12.

55. Almeda R, Cosgrove S, Buskey EJ. Oil spills and dispersants can cause the initiation of potentially harmful dinoflagellate blooms ("Red Tides"). Environ Sci Technol. 2018;52(10):5718-24.

56. Jernelöv A. Ixtoc I: A case study of the world's largest oil spill. Ambio. 1981;10(6):299-306 Royal Swedish Academy of Sciences.

57. FWC Fish and Wildlife Research Institute. Ceratium species bloom, offshore Florida Panhandle, May 10, 2010. https://www.flickr.com/photos/myfwc/6442824005. Accessed 5 May 2019.

58. Guo J, Liu X, Xie Q. Characteristics of the Bohai Sea oil spill and its impact on the Bohai Sea ecosystem. Chin Sci Bull. 2013;58(19):2276-81.

59. Ozhan K, Bargu S. Responses of sympatric Karenia brevis, Prorocentrum minimum, and Heterosigma akashiwo to the exposure of crude oil. Ecotoxicology. 2014;23(8):1387-98.

60. Adekunle IM, Ajijo MR, Adeofun CO, Omoniyi IT. Response of four phytoplankton species found in some sectors of Nigerian coastal waters to crude oil in controlled ecosystem. Int $\mathrm{J}$ Environ Res. 2010;4(1):65-74.

61. Hook SE, Osborn HL. Comparison of toxicity and transcriptomic profiles in a diatom exposed to oil, dispersants, dispersed oil. Aquat Toxicol. 2012;124-125:139-51.

62. Ozhan K, Bargu S. Distinct responses of Gulf of Mexico phytoplankton communities to crude oil and the dispersant corexit ${ }^{\circledR}$ Ec9500A under different nutrient regimes. Ecotoxicology. 2014;23(3):370-84.

63. González J, Figueiras FG, Aranguren-Gassis M, Crespo BG, Fernández E, Morán XAG, et al. Effect of a simulated oil spill on natural assemblages of marine phytoplankton enclosed in microcosms. Estuar Coast Shelf Sci. 2009;83(3):265-76.

64. Dunstan WM, Atkinson LP, Natoli J. Stimulation and inhibition of phytoplankton growth by low molecular weight hydrocarbons. Mar Biol. 1975;31(4):305-10.

65. Gobler CJ, Doherty OM, Hattenrath-Lehmann TK, Griffith AW, Kang Y, Litaker RW. Ocean warming since 1982 has expanded the niche of toxic algal blooms in the North Atlantic and North Pacific oceans. Proc Natl Acad Sci USA. 2017;114(19):4975-80.

66. Vancouver Coastal Health. Lower Mainland Facilities Management. Moving towards climate resilient health facilities for Vancouver Coastal Health. 2018.

67. Wells ML, Trainer VL, Smayda TJ, Karlson BS, Trick CG, Kudela RM, et al. Harmful algal blooms and climate change: learning from the past and present to forecast the future. Harmful Algae. 2015;49:68-93.

68. Hallegraeff GM. Ocean climate change, phytoplankton community responses, and harmful algal blooms: a formidable predictive challenge. J Phycol. 2010;46(2):220-35.

69. Sutherland D. Water Quality Objectives Attainment Monitoring in Burrard Inlet in 2002. Environmental Quality Section, Ministry of Water, Land and Air Protection.; 2004. https://www2.gov.bc.ca/ assets/gov/environment/air-land-water/water/waterquality/wqgs-wqos/wq-attainment-report-archi ve/sechelt_inletattainment2002.pdf. Accessed 5 May 2019.

70. Phippen B. Assessment of Burrard Inlet Water and Sediment Quality 2000. Water Protection Branch, Ministry of Water, Land and Air Protection; 2001. https://www2.gov.bc.ca/assets/gov/envir onment/air-land-water/water/waterquality/monitoring-water-quality/assessment_of_burrard_inlet _water_and_sediment_quality.pdf. Accessed 5 May 2019.

71. Tsleil-Waututh Nation. Burrard Inlet Action Plan. 2017. https://twnsacredtrust.ca/burrard-inlet-actio n-plan/. Accessed 5 May 2019. 
72. Bolton JL, Stehr CM, Boyd DT, Burrows DG, Tkalin AV, Lishavskaya TS. Organic and trace metal contaminants in sediments and English sole tissues from Vancouver Harbour, Canada. Mar Environ Res. 2004;57(1-2):19-36.

73. Gunton T, Broadbent S. An Assessment of Spill Risk for the Tran Mountain Expansion Project. 2015. https://twnsacredtrust.ca/wp-content/uploads/2015/05/TWN- Assessment-Appendix-1.pdf. Accessed 5 May 2019.

74. The Canadian Press. Arrests made as RCMP dismantle pipeline protest camp 2018 https://www. ctvnews.ca/business/arrests-made-as-rcmp-dismantle-pipeline-protest-camp-1.4055344. Accessed 5 May 2019.

75. UBCIC. UBCIC Presentation to Kinder Morgan TMX Project Ministerial Panel. 2016. https://d3n8a 8pro7vhmx.cloudfront.net/ubcic/pages/1302/attachments/original/1471646725/2016Aug17_UBCIC _BN_TMXMinisterialPanel_FINAL.pdf?1471646725. Accessed 5 May 2019.

76. City of Vancouver. Written Argument of the City of Vancouver. 2019. https://apps.neb-one.gc.ca/ REGDOCS/Item/View/3747668. Accessed 5 May 2019.

77. National Energy Board. NEB releases Reconsideration report for Trans Mountain Expansion Project 2019. http://www.neb-one.gc.ca/bts/nws/nr/2019/nr04-eng.html. Accessed 5 May 2019.

78. Lacy RC, Balcomb III KC, Brent LJN, Croft DP, Clark CW, Paquet PC. Report on Population Viability Analysis model investigations of threats to the Southern Resident Killer Whale population from Trans Mountain Expansion Project. Rain Coast Foundation; 2015. http://www.raincoast.org/ wp-content/uploads/2015/05/RCF-SRKW-PVA-for-NEB-May-2015.pdf. Accessed 5 May 2019.

79. Spiegel SJ. EIAs, power and political ecology: situating resource struggles and the techno-politics of small-scale mining. Geoforum. 2017;87:95-107.

80. Leonard L. Examining environmental impact assessments and participation: the case of mining development in Dullstroom, Mpumalanga, South Africa. J Environ Assess Policy Manag. 2017;19(01):1750002.

81. Li F. Unearthing conflict: corporate mining, activism, and expertise in Peru. Durham: Duke University Press; 2015.

82. Wilson LG. Trans Mountain is not in the public's interest-and we do not consent to it. 2019. https ://www.theglobeandmail.com/opinion/article-trans-mountain-is-not-in-the-publics-interest-andmust-not-be/?fbclid=IwAR21SNtc8o2xzmtMYvx8E0kd4-Wr6gSfsCEe-HHTvEvnzvHcihM9C22hI CI. Accessed 18 June 2019.

83. Buse CG, Lai V, Cornish K, Parkes MW. Towards environmental health equity in health impact assessment: innovations and opportunities. Int J Public Health. 2018;64(1):15-26.

84. Gillingham MP, Halseth GR, Johnson CJ, Parkes MW. The integration imperative: cumulative environmental, community and health impacts of multiple natural resource developments. Cham: Springer; 2016.

85. Westman CN, Joly TL. Oil Sands Extraction in Alberta, Canada: a Review of Impacts and Processes Concerning Indigenous Peoples. Human Ecology. 2019;47(2):233-43. https://doi.org/10.1007/ s10745-019-0059-6.

Publisher's Note Springer Nature remains neutral with regard to jurisdictional claims in published maps and institutional affiliations.

Michael E. Jonasson, MPH, MSc is a Graduate Academic Assistant in the Division of Occupational and Environmental Health at the School of Population and Public Health at the University of British Columbia (UBC), Vancouver, Canada.

Samuel J. Spiegel, PhD is a Senior Lecturer in International Development in the School of Social and Political Science at the University of Edinburgh, Scotland, UK, where he holds an Economic and Social Science Research Council Future Research Leader Fellowship.

Sarah Thomas is a Research Assistant in the Faculty of Health Sciences at Simon Fraser University (SFU) in Canada and is a member of Tsleil-Waututh Nation (TWN), where she served as Director of Communications for TWN. 
Annalee Yassi, MD, MSc, FRCPC is a specialist in Public Health and Preventive Medicine, holds a Canada Research Chair in Global Health and Capacity Building, and is a Professor in the School of Population and Public Health at UBC, Vancouver, British Columbia, Canada.

Hannah Wittman, PhD is a Professor in the Institute of Resources, Environment and Sustainability, as well as Land and Food Systems at UBC, and is the Academic Director, Centre for Sustainable Food Systems at UBC Farm, British Columbia, Canada.

Tim Takaro, MD, MPH is a physician-scientist trained in occupational and environmental medicine, public health and toxicology, is a Professor and Associate Dean for Research in the Faculty of Health Sciences at SFU, and a member of the Burnaby Residents Opposed to the Kinder-Morgan Expansion, Burnaby, Canada.

Reza Afshari, MD is an Adjunct Professor in the School of Population and Public Health at UBC and a Senior Scientist in toxicology and epidemiology at the BC Centre for Disease Control where he focuses on marine toxicology, British Columbia, Canada.

Michael Markwick, PhD is a Lecturer in the School of Communications at Capilano University, North Vancouver, British Columbia, Canada, and is the TWN-designated research coordinator on the Takaya project in which this synthesis is embedded.

Jerry M. Spiegel, PhD a Professor in the School of Population and Public Health, is co-director of the Global Health Research Program, a WHO Collaborating Centre in in Occupational and Environmental Health, and is the Principle Investigator of the food sovereignty and health equity research program, Vancouver, British Columbia, Canada, supported by the Canadian Institutes of Health Research. 